Kutatásvezető, egyetemi tanár PTE KPVK

\title{
A jogtörténet új forrásairól A Jogi Kultúrtörténeti és Jogi Néprajzi Digitális Adattár (DDFL) ${ }^{1}$
}

A tudományközi kutatások folytatására alakult meg 2011-ben Szekszárdon a Tárkány Szücs Ernő Jogi Kultúrtörténeti és Jogi Néprajzi Kutatócsoport a PTE Illyés Gyula (jelenleg Kultúratudományi, Pedagógusképző és Vidékfejlesztési) Kar, a PTE Állam- és Jogtudományi Kar Jogtörténet Tanszéke és a PTE ÁJK „A magyar jogrendszer megújítása a jogállamiság és az európai integráció jegyében” Doktori programja, az ELTE Állam- és Jogtudományi Kar Magyar Államés Jogtörténeti Tanszék és a Szegedi Tudományegyetem Állam- és Jogtudományi Kar Magyar Állam- és Jogtörténeti Tanszék támogatásával. A Kutatócsoport célja tagjai kutatási eredményeinek szakmai előadások és tanulmányok formájában történő ismertetése, a hazai és nemzetközi egyetemi és intézményi kapcsolatok erősítése, a kutatóvá formálódás, nevelődés segítése, a terület iránt érdeklődő doktoranduszok, fiatal kutatók támogatása. Küldetésnyilatkozatában is vállalt feladatai megvalósítását 2013-tól a pályázati idôszakban egy OTKA-kutatási projekt is támogatta.

A 2013. október 1. és 2018. szeptember 30. között megvalósult pályázat legfontosabb célja a jogtörténeti kutatások új, vagy eddig kevéssé ismert, illetve nehezen hozzáférhető forráscsoportokkal történő gazdagítása volt. A kihívást az jelentette, hogy mindezt a 21. század kutatói igényeinek megfelelő elvárásokhoz kellett igazítani. Innovatív módon élve a digitalizálás lehetôségeivel, a szakmaiság és a széles körű hozzáférés biztosításával teremtettük meg a legoptimálisabb forráshasználat lehetőségét a jogtörténet és a kapcsolódó interdiszciplináris kutatási területek (pl. jogi kultúrtörténet, jogi néprajz, történettudomány) akár eltérő nemzedékekhez tartozó kutatói számára egy modellértékű Digitális Adattár (DDFL) kialakításával (www.jogineprajz.hu). Ehhez szükséges volt a jogtörténeti kutatások horizontjának kiszélesítése (elsősorban a jogi kultúrtörténet, jogi néprajz, történettudomány, néprajz és szociológia metszetében), amely nem valósulhatott volna meg olyan, az érintett kutatási területeken már tapasztalattal és elismertséggel rendelkező kutatók nélkül, akik vállalták az új szemléletű, komplex megközelítést, s ennek tükrében a kutatás izgalmas, de mindenképpen új kihívásait.

A jogtudomány, a jogtörténet kiváló múvelői közül Dr. Homoki-Nagy Mária PhD (jogtörténész, tanszékvezetô egyetemi tanár, SZTE ÁJK, Szeged) és Dr. Kajtár István DSc. (jogtörténész, prof. emeritus, PTE ÁJK, Pécs) vált a tudományos műhely tagjává. A történészeket Bánkiné Dr. Molnár Eræsébet DSc. (történész, ny. múzeumigazgató, Kiskunfélegyháza) képviselte, a néprajzot, a jogtudományt és a szociológiát fiatal kutatóként Dr. Bognár Szabina PhD (néprajzkutató,

${ }^{1}$ OTKA K 109191 sz. projekt. 
jogász, szociológus, tudományos munkatárs, MTA BTK Néprajztudományi Intézet, Budapest). A kutatásvezetői feladatokat Dr. Nagy Janka Teodóra PhD (jogtörténész, néprajzkutató, tanszékvezető egyetemi tanár, PTE KPVK, Szekszárd) látta el. Az OTKA-kutatócsoport kutatási asszisztense Szabó Ernő (közgazdász, ókortörténész) PhD-hallgató/doktorjelölt lett. Az OTKA-kutatócsoport munkájának folyamatosan részesei, segítői voltak a PTE KVPK szakkollégiumának hallgatói is (Bíró Dóra Esz̧ter, Gáspár Csilla Noémi és Molnár Viktória).

Az a körülmény, hogy az OTKA-kutatócsoport kutatói valamennyien egyben a Tárkány Szücs Ernő Jogi Kultúrtörténeti és Jogi Néprajzi Kutatócsoportnak is tagjai voltak, a szoros együttműködés során nagymértékben elősegítette a pályázat benyújtásakor megfogalmazott célok megvalósítását - különös tekintettel a témában folyó alapkutatások szakmai hátterének biztosítására. A pályázati időszakban megvalósult konferenciák, szakmai múhelybeszélgetések, megjelent kiadványok a Kutatócsoport ismertségéhez és „intézményesüléséhez”, a hazai és nemzetközi tudományos életbe történő beágyazódásához is hozzájárultak.

A kutatómunka négy évét a folyamatosság, a kutatócsoport tagjai, illetve a tudományterületek közötti szinergia megerősödése jellemezte. A kutatók forráskutatást végeztek nemzetközi és hazai levéltárakban, könyvtárakban, forrásfeltárást egyházi, községi és családi levéltárakban. Ennek eredményeként az OTKA-kutatás során a vállaltakat többszörösen meghaladó terjedelmú (554 ív - 8.875 oldal) digitalizált forrás került elhelyezésre az Adattárban. Az ugyancsak az Adattárban elhelyezett, a PTE Tudásközpont által kifejlesztett, a KPVK Könyvtára által kezelt, a továbbiakban is folyamatosan bővülő magyar és angol nyelvű bibliográfiakeresôben a pályázat lezárásakor 313 jogi kultúrtörténeti, jogi néprajzi publikáció szerepelt.

A terepkutatások során a Tolna megyei Bölcskén (2015. július 6-10.) elsôsorban jogismereti, joghatékonysági, társadalomnéprajzi és társadalomismereti vizsgálatokat végeztünk, amely során megállapításra került, hogy a kisközösség tagjainak mindennapi életét a célszerűség jegyében szabályozó saját közösségi normák, szabályok sajnos már rendkívül hiányosak és töredezettek voltak. Makón és Szentesen (2016. július 4-8.) a levéltári források adataihoz kapcsolódóan a jogismeret- és jogtudatvizsgálatok körében elsősorban az öröklési és végrendelkezési szokások változásait kutattuk. A terepkutatások eredményei - éppen úgy, ahogyan az elkészült interjúk adatai - forráselemzésekben, konferenciaelőadásokban, illetve a pályázat során publikált átfogó és összegző tanulmányokban meg is jelentek.

Kialakításra és feltöltésre került a már említett Jogi Kultúrtörténeti, Jogi Néprajzi Digitális Adattár (DDFL). Az Adattárban a digitalizált források és a témához kapcsolódó bibliográfia mellett kutatói életpálya ismertetések, kiadványfigyelések, recenziók is megtalálhatóak, illetve az OTKAkutatás során végzett levéltári, könyvtári és múzeumi adattári kutatások, az ezeket kiegészítő bibliográfia- és terepkutatások eredményei (http://jogineprajz.hu/ddfl).

A Kutatócsoport tagjai a négy év során 22 nemzetközi és 17 hazai konferencia előadást tartottak, 22 nemzetközi konferenciaközleményt, lektorált szakfolyóiratcikket, könyvfejezetet, összességében 51 publikációt adtak le (19 a Kutatócsoport, 32 más kiadó kiadványaiban jelent meg). A vállalt 3 monográfia mellett az OTKA-kutatás időszakában megjelent a Bognár Szabina által írt, a Magyar Néprajzi Társaság által kiadott monográfia is (Bognár Szabina: A népi jogélet kutatása Magyarországon. Budapest: Magyar Néprajzi Társaság, 2016. (Néprajzi értekezések 5.) Az OTKAkutatócsoport öt tagja 75 publikációt (monográfia, konferenciaközlemény, könyvfejezet, lektorált 
szakfolyóiratcikk, egyéb publikáció) írt a kutatási témában az OTKA-pályázati idôszak (2013-2018) alatt. Az elkészült publikációkat a nyílt hozzáférés (Open Access) normái szerint természetesen folyamatosan térítésmentesen olvashatóvá tettük.

Az OTKA-kutatás idôszakában folytatott intenzív publikációs tevékenység részeként szép számmal jelentek meg a jogi kultúrtörténethez, jogi néprajzhoz kapcsolódó tárgyú tanulmányok, amelyekről a Kutatócsoport honlapján olvasható híradás, illetve recenzió, könyvajánlás. Az OTKAprojekt és a Tárkány Szücs Ernő Jogi Kultúrtörténeti és Jogi Néprajzi Kutatócsoport kutatási eredményeinek közzétételét és szélesebb körben történő megismertetését tűzte célul a Jogi Kultúrtörténeti és Jogi Néprajzi Kiskönyvtár sorozat, amely nyolc kötetének bemutatójára és a Kutatócsoport tagjai által 2013-2018 között OTKA-támogatással megvalósuló kutatások eredményeinek ismertetésére is sor került (ELTE ÁJK, Budapest, 2018. szeptember 26. 13.30).

A Jogi Kultúrtörténeti, Jogi Néprajzi Kiskönyvtár megjelent kötetei is jelezték a közös kutatások megtermékenyítő eredményeit, az interdiszciplináris együttműködés szemléleti többletét, modellértékű megvalósulást jelentve a tudományközi együttműködésnek:

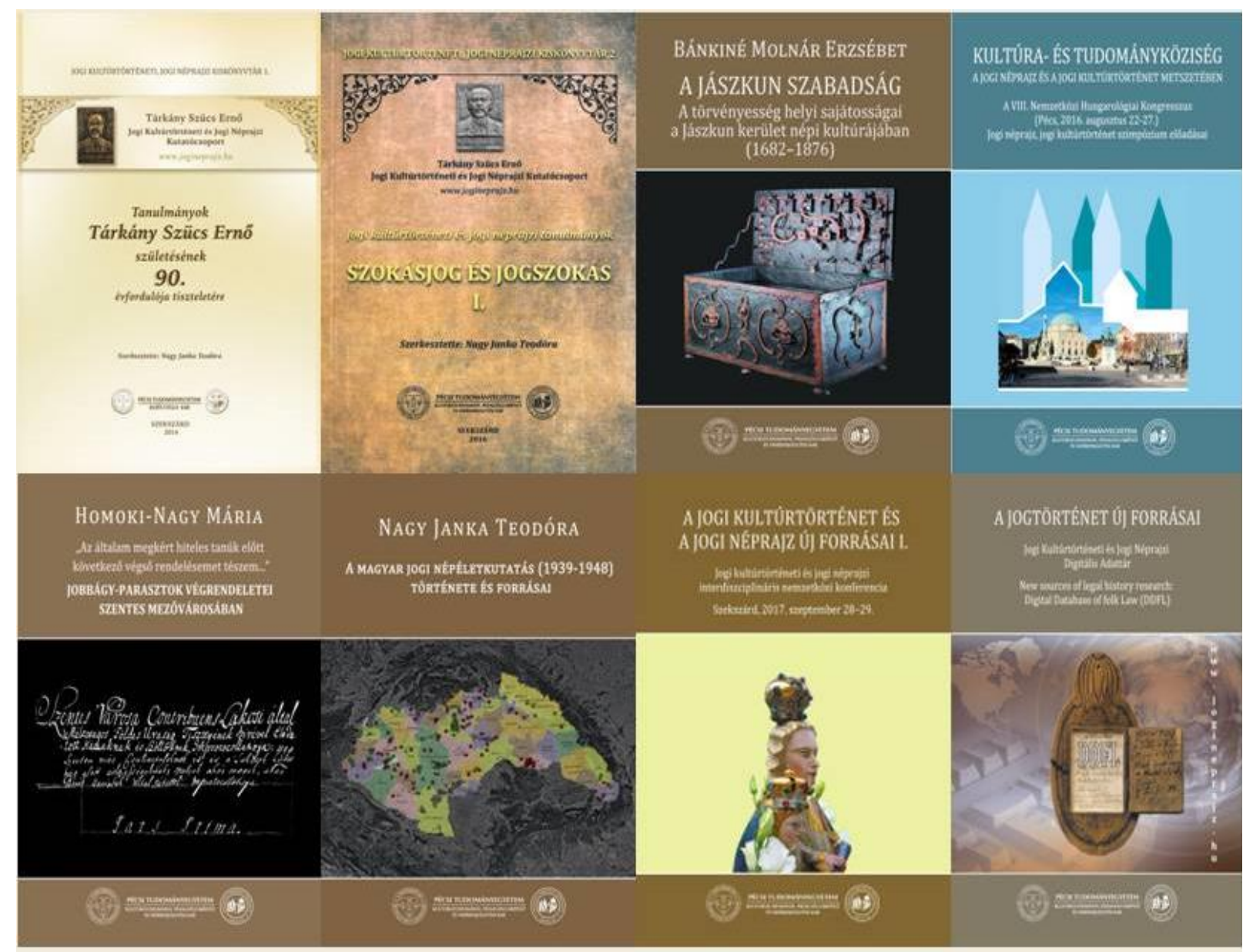

1. kötet Tanulmányok Tárkány Szücs Ernö sqülletésének 90. évfordulója tiszteletére (Tárkány Szücs Ernő Emléknap és Konferencia, Szekszárd, 2011. október 5.), PTE IGYK, Szekszárd, 2014.

2. kötet: Szokásjog és jogszokás I-II. (Jogi kultúrtörténeti és jogi néprajzi tanulmányok) (Tárkány Szücs Ernő 
jogi kultúrtörténeti és jogi néprajzi interdisziplináris konferencia, Szekszárd, 2014. október 2-3.), PTE KPVK, Szekszárd, 2016.

3. kötet: Bánkiné Molnár Erssébet: A jásžkun szabadság (A törvényesség helyi sajátosságai a Jászkun kerület népi kultúrájában 1682-1876). PTE KPVK, Szekszárd, 2017.

4. kötet: Kultúra- és tudományköz̨iség a jogi néprajz és a jogi kultúrtörténet metszetében. (A VIII.

Nemzetközi Hungarológiai Kongresszus Jogi néprajz, jogi kultúrtörténet szimpóziumának előadásai, Pécs, 2018. augusztus 24.), PTE KPVK, Szekszárd, 2018.

5. kötet: Homoki-Nagy Mária: „Az általam megkért hiteles tanúk elótt következô" végső rendelésemet tészem...” Jobbágy-parasz̧tok végrendeletei Sz̧entes mezốvárosában. PTE KPVK, Szekszárd, 2018.

6. kötet: Nagy Janka Teodóra: A magyar jogi népéletkutatás (1939-1948) története és forrásai. PTE KPVK, Szekszárd, 2018.

7. kötet: A jogi kultúrtörténet és a jogi néprajz új forrásai I-II. (Jogi kultúrtörténeti és jogi néprajzi interdiszciplináris nemzetközi konferencia Szekszárd, 2017. szeptember 28-29.) PTE KPVK, Szekszárd, 2018.

8. kötet: A jogtörténet új forrásai („A jogtörténeti kutatások új forrásai: jogi kultúrtörténeti, jogi néprajæi digitális adattár” K 109191 számú OTKA kutatás zárókiadványa). PTE KPVK, Szekszárd, 2018.

Az OTKA-kutatási projekt megvalósításához a PTE KPVK biztosította az infrastrukturát, a Tárkány Szücs Ernő Kutatócsoport a szakmai hátteret és a szakmai disszeminációt a pályázati kutatási eredmények és tudományos teljesítmények hazai és nemzetközi kutatásokba történő beépülésére. A disszemináció változatos színterei (honlap és virtuális tér, nyomtatott sajtó, média, nemzetközi és hazai konferenciák, könyvbemutatók, múhelybeszélgetések, nemzetközi és hazai szakfolyóiratok, doktori iskolák) és formái (hírek, beszámolók, programtájékoztatók, nemzetközi és hazai konferenciaelőadások, konferenciaközlemények, lektorált szakfolyóiratokban tanulmányok, recenziók, médiainterjúk, doktori iskolai előadások, tudományos ismeretterjesztések) szolgálták az OTKA-pályázat kutatási eredményeinek mind szélesebb szakmai és társadalmi körben történő megismertetését.

Nemzetközi színtéren az OTKA-Kutatócsoport részérôl bekapcsolódtunk tudományos nemzetközi szakmai szervezetek munkájába (Commision on Legal Pluralism, International Society for Ethnology and Folklore), kutatási együttmúködést kezdeményeztünk (Национальная научная библиотека РСО-А^ания, Oroszország, Vlagyikavkaz, СОИГСИ, Oroszország, Vlagyikavkaz).

A Kutatócsoport kiadványai megtalálhatóak: szakmai adatbázisokban, nemzetközi könyvtárakban, egyetemeken és kutatóintézetekben (pl. Library of Congress, USA, Wasington, Bibliothek des Leopold-Wenger-Instituts für Rechtsgeschichte, Bayerische und deutsche Rechtsgeschichte der Ludwig-Maximilians-Universität München, Национальная научная библиотека РСО-А^ания, Oroszország, Vlagyikavkaz, СОИГСИ, Oroszország, Vlagyikavkaz) és számos hazai könyvtárban, egyetemen, kutatóintézetben. 